\title{
Using Lesego Rampokoleng's Oeuvre to adress black consciousness and talent discovery: A case study in Teacher Education
}

\author{
Kgomotlokoa Linda Thaba- Nkadimene \& Duduzile Mzindle \\ Durban University of Technology, South Africa
}

\begin{abstract}
African youth are discouraged to pursue Arts disciplines due to the fact that there is minimal exposure to role models of African Artist such as Lesego Rampolokeng. A lack of preservation and exposure of African Artists Oeuvre's in Arts and Design has robbed interests in pursuing Art as a career. The study of indigenous knowledge of African Arts and role modelling can go a long way towards promoting self- awareness and talent discovery.

The purpose of this study is to examine the views of students on the works of Rampolokeng, a renowned African Artist. Black consciousness Theory and interepretivist paradigm were used to illuminate students' views on the lessons from Ramapokoleng artistic works.

The key findings of the study indicate that black consciousness lessons of Rampolokeng evoke students' self -awareness and become self-propelled towards self- actualised career life. Furthermore, Rampolokeng is regarded as a role model who promote students talent discovery.

We therefore recommend that performing Arts should become compulsory in foundational education of the South Africans. There should be increase exposure of African performing Arts works in the school curriculum.
\end{abstract}

Key words: African Oeuvre, Black consciousness, indigenous knowledge, role modelling, talent discovery. 